\title{
Dehydrogenase activity of forest soils depends on the assay used**
}

\author{
Kazimierz Januszek ${ }^{1 *}$, Ewa Błońska ${ }^{1}$, Joanna Długa ${ }^{1}$, and Jarosław Socha ${ }^{2}$ \\ ${ }^{1}$ Department of Forest Soil Science, ${ }^{2}$ Department of Biometry and Forest Productivity, \\ University of Agriculture in Kraków, 29 Listopada 46, 31-425 Kraków, Poland
}

Received November 18, 2013; accepted August 28, 2014

\begin{abstract}
A b s t r a c t. Dehydrogenases are exclusively intracellular enzymes, which play an important role in the initial stages of oxidation of soil organic matter. One of the most frequently used methods to estimate dehydrogenase activity in soil is based on the use of triphenyltetrazolium chloride as an artificial electron acceptor. The purpose of this study was to compare the activity of dehydrogenases of forest soils with varied physicochemical properties using different triphenyltetrazolium chloride assays. The determination was carried out using the original procedure by Casida et al., a modification of the procedure which involves the use of $\mathrm{Ca}(\mathrm{OH})_{2}$ instead of $\mathrm{CaCO}_{3}$, the Thalmann method, and the assay by Casida et al. without addition of buffer or any salt. Soil dehydrogenase activity depended on the assay used. Dehydrogenase determined by the Casida et al. method without addition of buffer or any salt correlated with the $\mathrm{pH}$ values of soils. The autoclaved strongly acidic samples of control soils showed high concentrations of triphenylformazan, probably due to chemical reduction of triphenyltetrazolium chloride. There is, therefore, a need for a sterilization method other than autoclaving, ie a process that results in significant changes in soil properties, thus helping to increase the chemical reduction of triphenyltetrazolium chloride.

K e y w o r d s: dehydrogenase activity, forest soils, triphenyltetrazolium chloride assays
\end{abstract}

\section{INTRODUCTION}

Dehydrogenases are exclusively intracellular enzymes, which play an important role in the initial stages of oxidation of soil organic matter by transferring electrons or hydrogen from substrates through co-enzymes to accep-

\footnotetext{
*Corresponding author e-mail: rljanusz@cyf-kr.edu.pl

**This work was partly financed by the State Forests National Forest Holding in Poland within the project: 3/08-Forest management measures improving the growth, nutrition, and health conditions in forest regeneration areas and endangered stands in the Beskidy Mts, with particular emphasis on soil revitalization with dolomites and new multi-component long-acting fertilizers.
}

tors. In aerobic conditions, $\mathrm{O}_{2}$ is the final electron acceptor (Camiña et al., 1998; Ross, 1971; Rossel and Tarradellas, 1991; Wolińska, 2010). The activity of dehydrogenases is measured to evaluate the overall microbial activity in soil (Alef and Nannipieri, 1995; Beyer at al. 1993; Casida et al., 1964; Lenhard, 1956), which plays a key role in organic matter dynamics, nutrient cycling, degradation of residues, and development of soil structure and aggregation (Paradelo and Barral, 2009). Soil enzyme activities are considered to be sensitive to pollution and have been proposed as indicators for measuring the degree of soil degradation, soil quality and soil health (Brookes, 1995; Gajda et al. 2013; Trasar-Cepeda et al., 2000), revegetation of a post mining sites (Chodak et al., 2009;), and the effect of different fertilization (Skawryło-Bednarz and Krzepiłko, 2009). Both soil moisture and physical conditions may influence biological activity by affecting the habitat and conditions for the life of microorganisms (Paradelo and Barral, 2009).

Dehydrogenase activity is measured by two methods based on the use of triphenyltetrazolium chloride (TTC) and iodonitrotetrazolium chloride (INT) substrate (Benefield et al., 1977; Friedel et al., 1994; Gong, 1997). TTC and INT have mainly been used as electron acceptors. However, several disadvantages have been described for these compounds. TTC is toxic for microorganisms; it has low reactivity requiring long incubation times and is reduced by different microorganisms at different rates. Moreover, TTC reduction is inhibited by $\mathrm{O}_{2}$ and only a small percentage of transferred electrons are recorded. The use of INT partly avoids these disadvantages because it is reduced more rapidly, less inhibited by oxygen, and less

(C) 2015 Institute of Agrophysics, Polish Academy of Sciences 
toxic to microorganisms (Von Mersi and Shinner, 1991). However, INT is more expensive and less water-soluble than TTC and its reduction is sensitive to soil composition (Malkomes, 1996). Therefore, one of the most frequently used methods to estimate dehydrogenase activity in soil is based on the use of triphenyltetrazolium chloride (TTC) as an artificial electron acceptor (Alef and Nannipieri 1995; Brzezińska et al., 2001; Klose et al., 2006; Januszek et al., 2007; Włodarczyk et al., 2002), generally called 'the TTC method'. Investigations by Stevenson (1959) have shown a correlation between the reduction of TTC and $\mathrm{O}_{2}$ uptake in some Canadian soils.

Metal ions $\left(e g \mathrm{Mn}^{2+}, \mathrm{Mg}^{2+}, \mathrm{Zn}^{2+}, \mathrm{Ca}^{2+}\right.$ or less frequently $\left.\mathrm{Co}^{2+}, \mathrm{Cu}^{2+}, \mathrm{Ni}^{2+}\right)$, or anions associated with protein $\left(\mathrm{Cl}^{-}\right)$ may serve as enzyme activators, whose action is affected by environmental factors, such as moisture, temperature, and $\mathrm{pH}$ (Wolińska, 2010). Soils with different properties may not provide optimal conditions for estimating the dehydrogenase activity (Ross, 1971). For example, the reduction of TTC is favoured by slightly alkaline conditions (Ross, 1971). In general, the optimal $\mathrm{pH}$ range for the activity of enzymes related to the redox reactions is 7.4-8.5 (Trevors, 1984). Dehydrogenase activity clearly decreases with decreasing $\mathrm{pH}$ of soil samples from the initial value of 7.7. Very low activity was found below the $\mathrm{pH}$ of 6.6 and above the $\mathrm{pH}$ of 9.5. The use of $\mathrm{CaCO}_{3}$ in the determination of DhA in forest soils as suggested by Lenhard (1956) using the procedure by Casida et al. (1964) or the use of a buffer as proposed by the Thalmann method (Alef and Nannipieri, 1995) did not provide the optimal $\mathrm{pH}$ for dehydrogenase activities (Januszek et al., 2007). The use of $\mathrm{Ca}(\mathrm{OH})_{2}$ and $\mathrm{Na}_{2} \mathrm{CO}_{3}$, instead of $\mathrm{CaCO}_{3}$, increased the formazan concentration, in the determination of dehydrogenase activity of forest soil. Furthermore, sterilization of soil samples by autoclaving and successive incubation with TTC significantly increased the amount of formazan, indicating chemical reduction of TTC (Januszek et al., 2007).

The initial hypothesis proposes that the currently recommended method for determining the activity of dehydrogenases in the soil by the TTC method on based on addition of buffers or salts to a soil suspension in order to obtain optimal $\mathrm{pH}$ for dehydrogenases is not adjusted (useful) for determination of potential dehydrogenase activity in forest soil.

The aim of the present study was to compare the activity of dehydrogenases of forest soils from southern Poland determined by the Thalmann method (Alef and Nannipieri, 1995), the original procedure by Casida et al. (1964), and modifications of the latter method consisting in not using any buffer or using $\mathrm{Ca}(\mathrm{OH})_{2}$ instead of $\mathrm{CaCO}_{3}$, which provides $\mathrm{pH}$ closer to the optimum for dehydrogenase activity. In the method without addition of buffers and $\mathrm{pH}$ adjusting salts, dehydrogenase activity determination was performed under conditions of the natural $\mathrm{pH}$ of the soil. The determined dehydrogenase activities were correlated with the physical, physicochemical, and chemical properties of soils. A significant correlation between dehydrogenase activity determined by a given method with properties related to soil quality or absence of a correlation may be an indicator of correct determination of DhA.

\section{MATERIALS AND METHODS}

Podzols, Endoeutric Cambisols, and Rendzic Leptosols (limestone soils) were sampled from the upper soil layer. Test samples were collected in summer 2010 from the upper horizons of the soils. The samples varied in terms of the particle size, $\mathrm{pH}$, content, and quality of organic matter. Soils were sampled to provide fresh material. Immediately after soil sampling, the samples were divided into two parts (subsamples): one part was used for determining dehydrogenase activity and the other part for determining both physical and chemical properties. In the first case, the soil samples were sieved $(<2 \mathrm{~mm})$ and stored until analysis (ie for up to two weeks) at $4^{\circ} \mathrm{C}$. The samples to be analyzed for their physical and chemical properties were dried in the laboratory and sieved $(<2 \mathrm{~mm})$. During soil sampling, forest litter was excluded.

Six Gleyic Podzols (WRB, 2006) samples were taken from sandy humus-eluvial AE horizons on six randomly selected sites in the Niepołomice Forest $\left(50^{\circ} 1^{\prime} 4.14 \mathrm{~N}\right.$ $20^{\circ} 14^{\prime} 13.48 \mathrm{E}$ ). Four Albic Pozols soils were collected from $\mathrm{AE}$ levels on four randomly selected sites located in the Olkusz Upland (50¹9'52.45N 19³4'50.34E). Ten Rendzic Leptosols (Calcaric Cambisols) were collected on 10 randomly selected sites in the upland areas surrounding Zabierzow (506'54.12N 1947'12.42E) near Kraków and in the Olkusz Upland from Ah mineral-humus horizons. The remaining 24 soil samples were taken in two series of 12 samples each, from the Oh or Ah horizons of Endoeutric Cambisol and from the Ofh horizon of Albic Podzol soil on experimental plots located in spruce forests in the Western

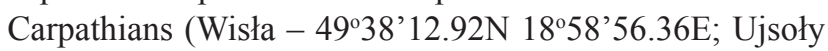
- $49^{\circ} 24^{\prime} 58.02 \mathrm{~N} 19^{\circ} 10^{\prime} 18.18 \mathrm{E}$ ), fertilized in 2008 with dolomite (D), magnesite (M) and serpentinite $(\mathrm{S})$ at rates of 4000 and $2000 \mathrm{~kg} \mathrm{ha}^{-1}$, respectively. A control plot (C), which was not fertilized, was also sampled.

Dehydrogenase activity (DhA) was determined by the following four assays:

- Assay 1: the Lenhard method using the original procedure by Casida et al. (1964); $40 \mathrm{~g}$ of field-moist soil were mixed with $400 \mathrm{mg}$ of $\mathrm{CaCO}_{3}$. Five 6-g portions of the soil mixture were placed in Nessler flasks $\left(50 \mathrm{~cm}^{3}\right)$ and three of them were treated with $1 \mathrm{ml}$ of a $3 \%$ aqueous TTC solution, while two 6-g weighed amounts of the soil mixture were treated with $1 \mathrm{ml}$ of distilled water. Next, all flasks were treated with distilled water to obtain $2 \mathrm{~mm}$ of water above the soil after mixing. This method is referred to as the 'DHA-CaCO ' assay. 
- Assay 2: the above procedure was modified by adding $300 \mathrm{mg}$ of $\mathrm{Ca}(\mathrm{OH})_{2}$ instead of $400 \mathrm{mg} \mathrm{CaCO}$ to $40 \mathrm{~g}$ of field-moist soil. Two 6-g portions of the soil were sterilized as control samples in the autoclave $\left(121^{\circ} \mathrm{C}, 20 \mathrm{~min}\right.$, for three consecutive days) and both the 3 measurement samples and the 2 control samples were treated with $1 \mathrm{ml}$ of a $3 \%$ aqueous TTC solution. This method is called the ' $\mathrm{DhA}-\mathrm{Ca}(\mathrm{OH})_{2}$ ' assay;

- Assay 3: determination of DhA was carried out according to the Thalmann method (Alef and Nannipieri, 1995) and this method is referred to as the "DhA-Th" assay;

- Assay 4: an aqueous TTC solution with the concentration and amount as recommended in the Thalmann method (Alef and Nannipieri, 1995) was added to $6 \mathrm{~g}$ of fieldmoist soil. The treatment was replicated three times. The same treatment was applied to the control samples after sterilization by autoclaving $\left(121^{\circ} \mathrm{C}, 1\right.$ atmosphere, $20 \mathrm{~min}$, for three consecutive days). The control was replicated twice. Distilled water was added to all samples to bring the water level at $2 \mathrm{~mm}$ above the soil. This assay is called the 'DhA-wb' since no buffer, $\mathrm{CaCO}_{3}$, or $\mathrm{Ca}(\mathrm{OH})_{2}$ were added.

All incubations were carried out in flat-bottomed glass tubes ( $155 \times 25 \mathrm{~mm}$ in diameter) with plastic stoppers. The incubation time for all the assays was 24 hours and the incubation was carried out in the dark at $37^{\circ} \mathrm{C}$ (methods 1,2 and 4) and at $30^{\circ} \mathrm{C}$ (method 3: 'DhA-Th'). The extraction of formazan was carried out under diffused light, with ethanol in samples analysed with the DhA determination methods Nos 1, 2 and 4 and with acetone in samples tested with the determination method No. 3: DhA-Th. Each extract containing TPF was filtered through Whatman grade 5 filter paper. The amount of TPF determined in the control samples was subtracted from the amount of TPF determined in the measurement samples. In addition, each determination batch had 2 control reagent samples without soil, in which TPF (in most cases zero or trace amounts of TPF) was subtracted from the contents determined in the measurement samples containing soil.

In the samples of field-moist soils prepared for DhA determination, the moisture was determined using the dryweight method. All analytical results are expressed on the basis of dry weight of soil in $\mu$ mol TPF kg of soil ${ }^{-1} \mathrm{~h}^{-1}$. Dry weight determinations were calculated after drying soil samples for $24 \mathrm{~h}$ at $105^{\circ} \mathrm{C}$.

In the samples dried at room temperature and sieved through a sieve with the $2 \mathrm{~mm}$ mesh, the following characteristics were determined (Lityński et al., 1976):

- granulometric composition using the Casagrande aerometric method as modified by Prószyński;

- soil $\mathrm{pH}$ in $\mathrm{H}_{2} \mathrm{O}$ and in $1 \mathrm{M} \mathrm{KCl}$ with the potentiometer while maintaining the soil solution rate of 1:2.5 (in mineral soils and humus-mineral soils) and 1:5 (in organic soils);
- hydrolytic acidity (total acidity $-\mathrm{H}_{\mathrm{T}}$ ) using the Kappen method in the extract of $1 \mathrm{M}$ of calcium acetate;

- total C and N using the CNS 2000 Leco elemental analyser with calculation of the $\mathrm{C}: \mathrm{N}$ ratio;

- exchangeable forms of calcium $\left(\mathrm{Ca}^{2+}\right)$, magnesium $\left(\mathrm{Mg}^{2+}\right)$, potassium $\left(\mathrm{K}^{+}\right)$, and sodium $\left(\mathrm{Na}^{+}\right)$in the extract of $1 \mathrm{M}$ of $\mathrm{CH}_{3} \mathrm{COONH}_{4}$ with $\mathrm{pH} 7.0$, determined on the spectrometer with inductively coupled plasma ICP OES iCAP 6000 Thermo Scientific Series, with calculation of the sum of base cations $(\mathrm{S})$ and sorption capacity $(\mathrm{T}=\mathrm{S}$ $+\mathrm{H}_{\mathrm{T}}$ ) and the degree of base saturation of the sorption capacity $\mathrm{V} \%(\mathrm{~V} \%=\mathrm{S} / \mathrm{T} * 100)$.

The relationships between the DhA level estimated with the use of the applied assays and individual physicochemical and chemical properties of the collected soil samples were described using Pearson correlation matrix. The PCA method was used in order to reduce the number of variables in the statistical data set and visualise the multivariate data set as a set of coordinates in a high-dimensional data space. The PCA method was also used in order to interpret factors depending on the kind of the data set. The multiple forward stepwise regression method was used to develop models describing the relationship between estimated values of DhA and soil characteristics and select those soil properties that have a considerable influence on DhA values. The significance of individual independent variables in multiple regression equations was tested using the $t$ test at a significance level of $\alpha=0.05$. Before including the independent variable in the model, its redundancy was estimated by calculating the variance inflation factor (VIF).

$$
V I F_{j}=1 / 1-R_{j}^{2}
$$

where: $R^{2}$ is the adjusted coefficient of determination between the independent variable $j$ and other independent variables.

The accuracy of the developed models was analyzed using the adjusted coefficient of determination $\left(R_{a d j}^{2}\right)$ and the root mean square error (RMSE). Homoscedasticity and the distribution of residual values against values predicted according to the models were both analysed graphically and tested using the White test. The homoscedasticity assumption means that the variance around the regression line does not vary with the effects being modelled. In the case of the absence of homoscedasticity, logarithmic and square root data transformations were used. Statistical analysis of the result was done using the StatSoft (2011).

\section{RESULTS}

Grain size, physicochemical properties, and moisture of the examined soil samples are summarized in Tables 1 and 2, and the chemical properties in Table 3. Based on the conducted PCA analysis, among the examined physical, physicochemical, and chemical properties of the soil samples adopted as active variables, three main factors 
T a b l e 1. Moisture and percent of soil fraction $(\mathrm{mm})$ of soils

\begin{tabular}{|c|c|c|c|c|c|c|c|}
\hline \multirow{2}{*}{\multicolumn{2}{|c|}{ Soil type/ Soil horizons }} & \multirow{2}{*}{$\begin{array}{l}\text { Statistic } \\
\text { parameters }\end{array}$} & \multirow{2}{*}{$\begin{array}{l}\text { Number of } \\
\text { repetitions }\end{array}$} & \multirow{2}{*}{$\begin{array}{l}\text { Soil moisture } \\
(\% \mathrm{w} / \mathrm{w})\end{array}$} & \multicolumn{3}{|c|}{ Percent of soil fraction $(\mathrm{mm})$} \\
\hline & & & & & $2.0-0.05$ & $0.05-0.002$ & $<0.002$ \\
\hline \multirow{3}{*}{\multicolumn{2}{|c|}{$\begin{array}{l}\text { Gleyic Podzol } \\
\text { AE }\end{array}$}} & minimum & & 10.33 & 89 & 2 & 3 \\
\hline & & maximum & 6 & 33.89 & 93 & 5 & 7 \\
\hline & & average & & 20.42 & 91 & 4 & 5 \\
\hline \multirow{3}{*}{\multicolumn{2}{|c|}{$\begin{array}{l}\text { Albic Podzol } \\
\text { AE }\end{array}$}} & minimum & & 4.58 & 92 & 1 & 3 \\
\hline & & maximum & 4 & 7.86 & 95 & 4 & 4 \\
\hline & & average & & 6.28 & 94 & 3 & 3 \\
\hline \multirow{4}{*}{\multicolumn{2}{|c|}{$\begin{array}{c}\text { Calcaric Cambisol } \\
\text { Ah }\end{array}$}} & minimum & & 10.55 & 66 & 4 & 5 \\
\hline & & maximum & 10 & 37.97 & 91 & 14 & 20 \\
\hline & & average & & 24.73 & 81 & 7 & 12 \\
\hline & & minimum & & 43.54 & 62 & 10 & 22 \\
\hline \multirow{10}{*}{$\begin{array}{c}\text { Endoeutric } \\
\text { Cambisol } \\
\text { Oh, Ah }\end{array}$} & \multirow[t]{3}{*}{$\mathrm{C}$} & maximum & 3 & 60.56 & 63 & 15 & 28 \\
\hline & & average & & 50.20 & 62.5 & 12.5 & 25 \\
\hline & & minimum & & 37.78 & 59 & 13 & 25 \\
\hline & \multirow[t]{3}{*}{$\mathrm{D}$} & maximum & 3 & 52.57 & 59 & 16 & 28 \\
\hline & & average & & 44.54 & 59 & 15 & 27 \\
\hline & & minimum & & 39.63 & 63 & 12 & 24 \\
\hline & \multirow[t]{3}{*}{ M } & maximum & 3 & 47.39 & 63 & 12 & 25 \\
\hline & & average & & 43.63 & 63 & 12 & 25 \\
\hline & & minimum & & 40.41 & 61 & 12 & 27 \\
\hline & \multirow[t]{3}{*}{$\mathrm{S}$} & maximum & 3 & 5.00 & 61 & 12 & 27 \\
\hline \multirow{13}{*}{$\begin{array}{l}\text { Albic Podzol } \\
\text { Ofh }\end{array}$} & & average & & 49.23 & 61 & 12 & 27 \\
\hline & & minimum & & 68.12 & & \multirow{12}{*}{ n.d. } & \\
\hline & $\mathrm{C}$ & maximum & 3 & 76.49 & & & \\
\hline & & average & & 71.40 & & & \\
\hline & & minimum & & 66.95 & & & \\
\hline & $\mathrm{D}$ & maximum & 3 & 74.63 & & & \\
\hline & & average & & 70.54 & & & \\
\hline & \multirow{4}{*}{ M } & minimum & & 63.14 & & & \\
\hline & & maximum & 3 & 74.00 & & & \\
\hline & & average & & 68.51 & & & \\
\hline & & minimum & & 69.68 & & & \\
\hline & \multirow[t]{2}{*}{$\mathrm{S}$} & maximum & 3 & 72.22 & & & \\
\hline & & average & & 70.97 & & & \\
\hline
\end{tabular}

$\mathrm{D}, \mathrm{M}$, and $\mathrm{S}$ - mean soils after dolomite, magnesite, and serpentinite fertilization, $\mathrm{C}$ - control, n.d. - not determined. 
T a b l e 2. Characteristics of selected physicochemical properties of soils

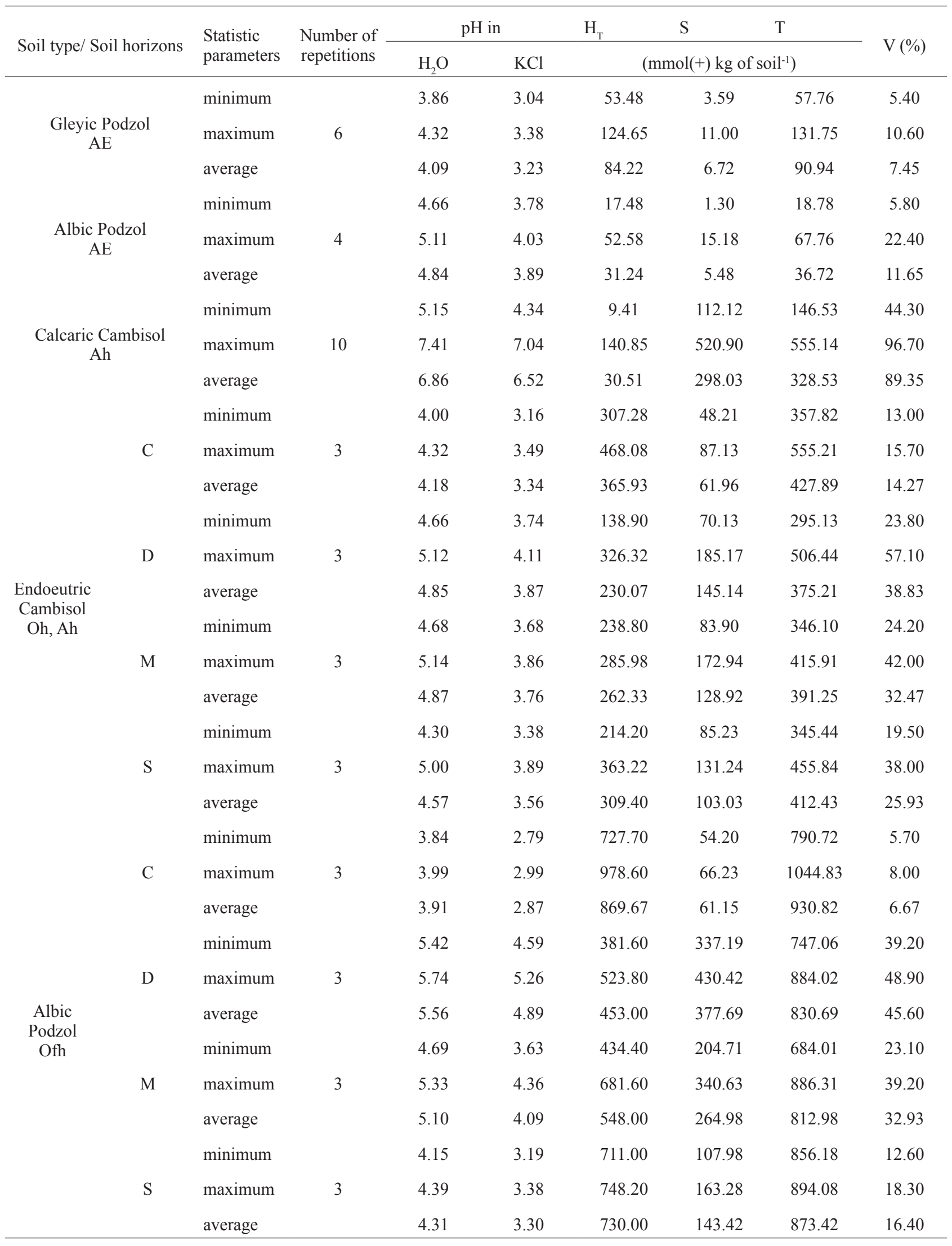

$\mathrm{H}_{\mathrm{T}}$ - total acidity, $\mathrm{S}$ - sum of base cations, $\mathrm{T}$ - sorption capacity, $\mathrm{V}$ - degree of base saturation (\%). Other explanations as in Table 1. 
T a b l e 3. Characteristics of selected chemical properties of soils

\begin{tabular}{|c|c|c|c|c|c|c|c|c|c|}
\hline \multirow{2}{*}{$\begin{array}{l}\text { Soil type/ } \\
\text { Soil horizons }\end{array}$} & \multirow{2}{*}{$\begin{array}{l}\text { Statistic } \\
\text { parameters }\end{array}$} & \multirow{2}{*}{$\begin{array}{l}\text { Number of } \\
\text { repetitions }\end{array}$} & Total C & Total N & \multirow{2}{*}{$\mathrm{C}: \mathrm{N}$} & $\mathrm{Ca}^{2+}$ & $\mathrm{Mg}^{2+}$ & $\mathrm{K}^{+}$ & $\mathrm{N}^{+}$ \\
\hline & & & \multicolumn{2}{|c|}{$(\%)$} & & \multicolumn{4}{|c|}{$\left(\mathrm{mmol}(+) \mathrm{kg}\right.$ of soil $\left.{ }^{-1}\right)$} \\
\hline \multirow{3}{*}{$\begin{array}{l}\text { Gleyic Podzol } \\
\text { AE }\end{array}$} & minimum & & 1.15 & 0.05 & 18.60 & 2.23 & 0.59 & 0.55 & 0.09 \\
\hline & maximum & 6 & 3.43 & 0.17 & 25.60 & 8.69 & 1.30 & 0.93 & 0.16 \\
\hline & average & & 2.08 & 0.10 & 22.07 & 4.90 & 0.94 & 0.77 & 0.11 \\
\hline \multirow{3}{*}{$\begin{array}{l}\text { Albic Podzol } \\
\text { AE }\end{array}$} & minimum & & 0.41 & 0.02 & 16.90 & 0.77 & 0.16 & 0.22 & 0.05 \\
\hline & maximum & 4 & 1.52 & 0.09 & 22.80 & 12.98 & 1.42 & 0.71 & 0.07 \\
\hline & average & & 0.80 & 0.04 & 19.28 & 4.49 & 0.53 & 0.40 & 0.06 \\
\hline \multirow{4}{*}{$\begin{array}{c}\text { Calcaric Cambisol } \\
\text { Ah }\end{array}$} & minimum & & 1.53 & 0.11 & 11.00 & 76.30 & 25.73 & 1.13 & 0.19 \\
\hline & maximum & 10 & 10.70 & 0.61 & 18.00 & 362.16 & 154.93 & 6.59 & 0.44 \\
\hline & average & & 4.65 & 0.30 & 15.12 & 229.65 & 64.58 & 3.51 & 0.28 \\
\hline & minimum & & 8.36 & 0.49 & 17.10 & 37.19 & 5.68 & 4.84 & 0.49 \\
\hline \multirow{6}{*}{$\begin{array}{c}\text { Endoeutric } \\
\text { Cambisol } \\
\text { Oh, Ah }\end{array}$} & maximum & 3 & 17.61 & 0.76 & 23.10 & 69.29 & 10.03 & 7.05 & 0.75 \\
\hline & average & & 11.70 & 0.58 & 19.57 & 48.22 & 7.49 & 5.60 & 0.64 \\
\hline & minimum & & 6.49 & 0.38 & 15.90 & 43.47 & 18.58 & 3.40 & 0.62 \\
\hline & maximum & 3 & 15.44 & 0.72 & 21.60 & 160.63 & 41.09 & 5.35 & 0.67 \\
\hline & average & & 9.53 & 0.50 & 18.40 & 112.61 & 27.42 & 4.47 & 0.65 \\
\hline & minimum & & 8.03 & 0.43 & 17.80 & 28.92 & 49.98 & 3.99 & 0.51 \\
\hline \multirow[t]{3}{*}{ M } & maximum & 3 & 12.52 & 0.58 & 21.70 & 89.56 & 71.00 & 11.30 & 1.09 \\
\hline & average & & 9.86 & 0.51 & 19.33 & 62.39 & 59.24 & 6.59 & 0.70 \\
\hline & minimum & & 7.07 & 0.44 & 15.90 & 42.22 & 19.00 & 3.46 & 0.44 \\
\hline \multirow[t]{3}{*}{$\mathrm{S}$} & maximum & 3 & 14.81 & 0.65 & 24.40 & 105.41 & 37.99 & 6.37 & 0.95 \\
\hline & average & & 12.21 & 0.57 & 21.07 & 70.32 & 27.40 & 4.63 & 0.67 \\
\hline & minimum & & 27.33 & 1.12 & 23.50 & 36.61 & 8.07 & 5.85 & 0.54 \\
\hline \multirow{6}{*}{$\begin{array}{l}\text { Albic } \\
\text { Podzol } \\
\text { Ofh }\end{array}$} & maximum & 3 & 40.54 & 1.49 & 27.10 & 50.89 & 8.98 & 7.91 & 0.90 \\
\hline & average & & 33.42 & 1.33 & 25.00 & 45.23 & 8.57 & 6.63 & 0.72 \\
\hline & minimum & & 26.98 & 1.06 & 25.20 & 201.59 & 129.33 & 5.72 & 0.56 \\
\hline & maximum & 3 & 31.58 & 1.23 & 28.00 & 266.97 & 156.66 & 6.12 & 0.67 \\
\hline & average & & 29.88 & 1.14 & 26.23 & 231.60 & 139.56 & 5.91 & 0.62 \\
\hline & minimum & & 24.99 & 1.02 & 24.50 & 37.03 & 158.54 & 6.05 & 0.40 \\
\hline \multirow[t]{3}{*}{ M } & maximum & 3 & 33.88 & 1.37 & 25.20 & 51.15 & 296.68 & 7.16 & 0.74 \\
\hline & average & & 30.13 & 1.21 & 24.80 & 42.15 & 215.74 & 6.48 & 0.62 \\
\hline & minimum & & 27.61 & 1.04 & 23.90 & 36.77 & 64.51 & 6.23 & 0.48 \\
\hline \multirow[t]{2}{*}{$\mathrm{S}$} & maximum & 3 & 34.20 & 1.42 & 26.50 & 50.44 & 109.57 & 7.74 & 0.67 \\
\hline & average & & 30.97 & 1.25 & 24.80 & 44.17 & 91.58 & 7.10 & 0.57 \\
\hline
\end{tabular}

Explanations as in Table 1. 
(components) were selected that have a significant total impact $(91.6 \%)$ on the variances of the variables. Factor 1 , which explains $50.1 \%$ of the variation, is strongly negatively correlated with the moisture of the samples (Wh), total acidity $\left(\mathrm{H}_{\mathrm{T}}\right)$, and cation sorption capacity $(\mathrm{T})$ (Fig. 1a). Factor 2 is strongly negatively correlated with properties such as the sum of base cations (S), content of exchangeable calcium, the degree of base saturation $(\mathrm{V} \%)$, and the values of $\mathrm{pH}$ in $\mathrm{KCl}$. This factor explains $\mathrm{ca} .33 \%$ of the variance of the examined properties (Fig. 1a). Factor 3 is positively correlated with the values of the $\mathrm{C}: \mathrm{N}$ ratio and the content of exchangeable magnesium $\left(\mathrm{Mg}^{2+}\right)$ and negatively correlated with the content of exchangeable potassium $\left(\mathrm{K}^{+}\right)$and sodium $\left(\mathrm{Na}^{+}\right)$; it explains $8.5 \%$ of the variance of active variables (Fig. 1b). The relationships between the main factors identified and the dehydrogenase activities determined using the applied assays are discussed below.

The average values of dehydrogenase activities in the examined soil types and varieties are summarized in Table 4 .

The values of formazan determined in the examined soil samples using the ' $\mathrm{DhA}-\mathrm{CaCO}_{3}$ ' assay ranged from 0.05 to $130.75 \mu \mathrm{mol}$ TPF kg of soil ${ }^{-1} \mathrm{~h}^{-1}$ (Albic Podzol - AE and Ofh $-\mathrm{D}$, respectively) (Table 4). The highest concentrations of formazan were detected in the samples from the Ofh horizons of Albic Podzol soil after fertilization with dolomite (D): an average value of $123.23 \mu \mathrm{mol}$ TPF $\mathrm{kg}$ of soil ${ }^{-1} \mathrm{~h}^{-1}$. Slightly lower TPF concentrations were found in the samples from the Ofh horizons of Albic Podzol after fertilization with magnesite (M): the mean value was $86.14 \mu \mathrm{mol}$ TPF kg of soil ${ }^{-1} \mathrm{~h}^{-1}$, and with serpentinite (S): an average concentration of $68.40 \mu \mathrm{mol} \mathrm{TPF} \mathrm{kg} \mathrm{of} \mathrm{soil-1}{ }^{-1} \mathrm{~h}^{-1}$ (Table 4). The lowest TPF concentrations (the mean value: $47.29 \mu \mathrm{mol} \mathrm{TPF} \mathrm{kg} \mathrm{of}$ soil $^{-1} \mathrm{~h}^{-1}$ ) were found in the samples from the Ofh horizon of Albic Podzol soil without fertilization (Table 4). At lower doses of the applied fertilizer $\left(2 \mathrm{tha}^{-1}\right)$ on the plot with Endoeutric Cambisol, there were no apparent differences in DhA depending on the type of the fertilizer used; the indicated TPF concentrations ranged in the samples from 9.63 to 25.36 with an average value of $17.64 \mu \mathrm{mol}$ TPF $\mathrm{kg}$ of soil $^{-1} \mathrm{~h}^{-1}$ (Table 4). In the samples obtained from the Ah horizons of Calcaric Cambisols, the determined TPF concentrations ranged from $10.94 \mu \mathrm{mol}$ TPF kg of soil-1 $\mathrm{h}^{-1}$ to $98.66 \mu \mathrm{mol}$ TPF kg of soil ${ }^{-1} \mathrm{~h}^{-1}$, with the mean concentration of TPF at the level of $46.67 \mu \mathrm{mol}$ TPF kg of soil ${ }^{-1} \mathrm{~h}^{-1}$ (Table 4). The lowest concentrations of $\mathrm{TPF}$ determined using the ' $\mathrm{DhA}-\mathrm{CaCO}_{3}$ ' procedure were detected in the samples from the AE horizons of Albic Podzols with an average activity of $2.58 \mu \mathrm{mol}$ TPF $\mathrm{kg}$ of soil $^{-1} \mathrm{~h}^{-1}$ (Table 4).

The results of the multiple regression analysis show that the TPF concentration values determined using the 'DhA- $\mathrm{CaCO}_{3}$ ' assay were significantly affected by such characteristics as the content of exchangeable magnesium $\left(\mathrm{Mg}^{2+}\right)$ and calcium $\left(\mathrm{Ca}^{2+}\right)$, cation sorption capacity $(\mathrm{T})$, and the content of total $\mathrm{C}\left(\mathrm{C}_{\mathrm{tot}}\right)$. The model describing the

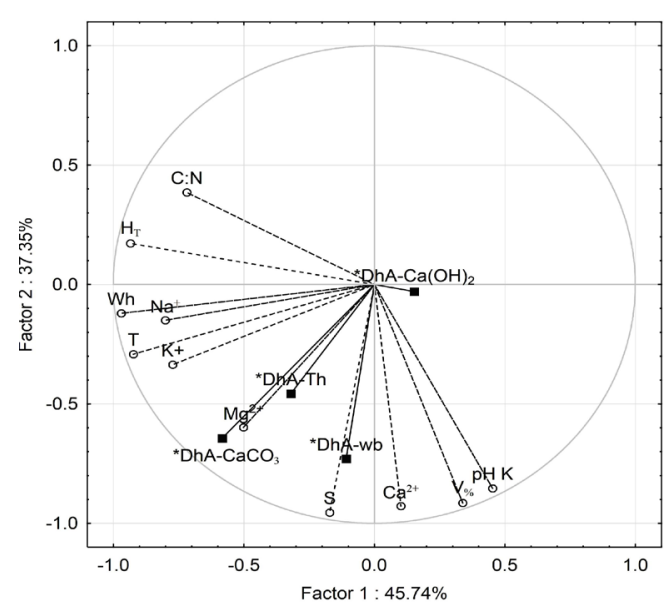

b

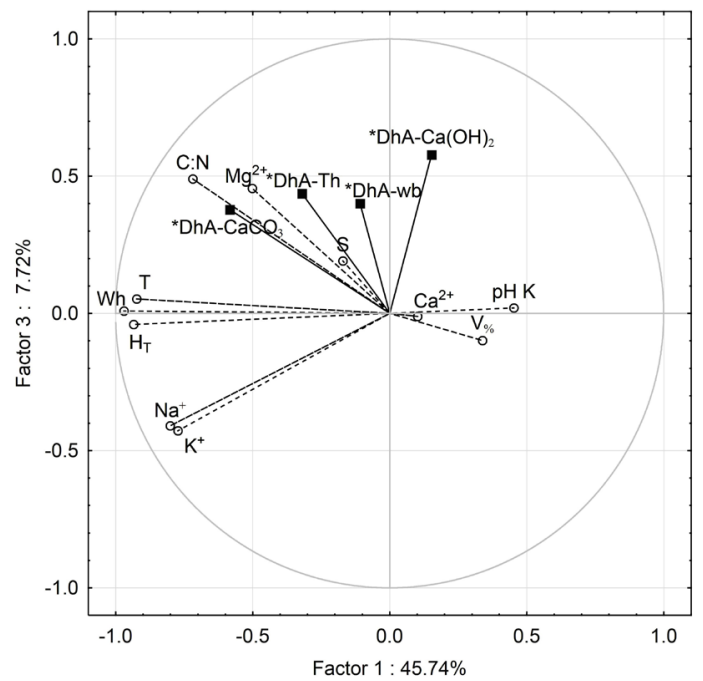

c

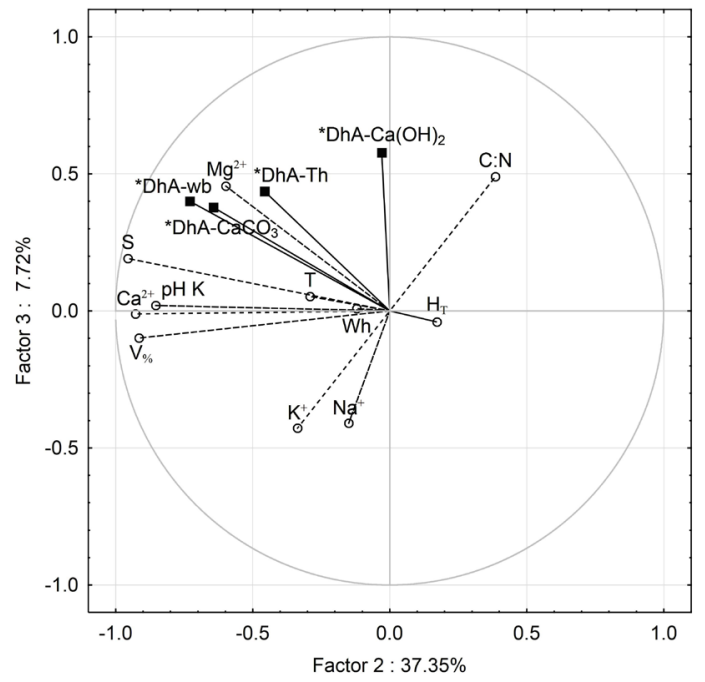

Fig. 1. Projection of variables (vectors marked with solid lines and circles) on the factor-plane: $\mathrm{a}-1 \times 2, \mathrm{~b}-1 \times 3, \mathrm{c}-2 \times 3$ with DhA estimates as additional variables (vector marked with dotted lines and squares), o active variables, a additional variables. 
T a b l e 4. Characteristics of dehydrogenase activities of soils

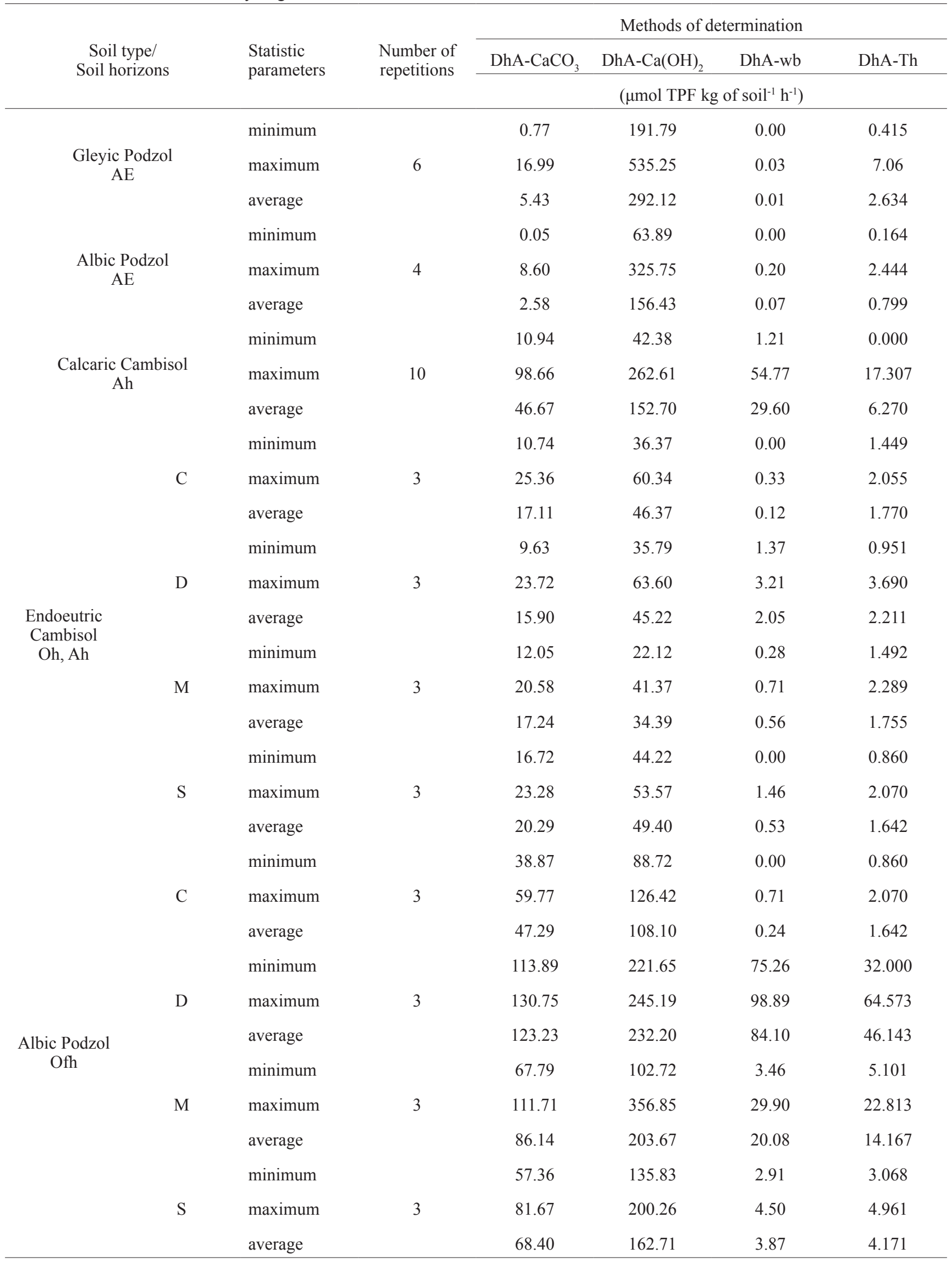

Explanations as in Table 1. 
dehydrogenase activity of the examined soils determined using the ' $\mathrm{DhA}-\mathrm{CaCO}_{3}$ ' assay as a function of the above variables explains over $90 \%$ of the variance $\left(R_{a d j}^{2}=\right.$ 0.901964, Eq. (2).

$$
\begin{aligned}
& \mathrm{DhA}-\mathrm{CaCO}_{3}=-0.120889+0.216105 \mathrm{Mg}^{2+}- \\
& 0.088257 \mathrm{~T}+0.196234 \mathrm{Ca}^{2+} 3.590365 \mathrm{C}_{\text {tot }}
\end{aligned}
$$

where: DhA-CaCO $-\mu$ mol TPF kg of dry soil ${ }^{-1} 1 \mathrm{~h}^{-1}, \mathrm{Mg}^{2+}$ and $\mathrm{Ca}^{2+}$ - exchangeable magnesium and calcium content in $\mathrm{mmol}(+) \mathrm{kg}$ of soil ${ }^{-1}, \mathrm{~T}-$ cation sorption capacity in mmol( +$) \mathrm{kg}$ of soil ${ }^{-1}, \mathrm{C}_{\text {tot }}-$ the content of total $\mathrm{C}$ in $\%$.

Dehydrogenase activities determined using the DhA$\mathrm{CaCO}_{3}$ assay were correlated both with factor 1 and 2, and slightly less correlated with factor 3 (Fig. 1).

The values of formazan determined in the examined soil samples using the ' $\mathrm{DhA}-\mathrm{Ca}(\mathrm{OH})_{2}$ ' assay were the highest in comparison with the amount of TPF determined with the other assays, and ranged from 22.12 to $535.25 \mu \mathrm{mol}$ TPF kg of soil ${ }^{-1} \mathrm{~h}^{-1}$ (Endoeutric Cambisol - $\mathrm{M}$ and Gleyic Podzol - AE, respectively). The highest average concentrations of TPF were determined in the samples from the AE horizons of Gleyic Podzols, while the lowest levels were found in the samples from the $\mathrm{Oh}$ and $\mathrm{Ah}$ horizons of Endoeutric Cambisol after fertilization with magnesite (M), with the mean concentration of 292.12 and $34.39 \mathrm{mmol}$ TPF kg of soil ${ }^{-1} \mathrm{~h}^{-1}$, respectively (Table 4 ).

The multiple regression analysis indicates that the dehydrogenase activity determined by ' $\mathrm{DhA}-\mathrm{Ca}(\mathrm{OH})_{2}$ ' is correlated with the amount of exchangeable magnesium $\left(\mathrm{Mg}^{2+}\right)$ and sodium $\left(\mathrm{Na}^{+}\right)$. The model (Eq. (3)), however, explains only $c a .30 \%$ of the variation of dehydrogenases determined with the 'DhA-Ca(OH $)_{2}$ ' method $\left(R^{2}{ }_{a d j}=\right.$ 0.2982).

$\mathrm{DhA}-\mathrm{Ca}(\mathrm{OH})_{2}=209.149+0.657 \mathrm{Mg}^{2+}-220.203 \mathrm{Na}^{+}$

where: $\mathrm{DhA}=\mathrm{Ca}(\mathrm{OH})_{2}$ in $\mu$ mol TPF kg dry soil ${ }^{-1} \mathrm{~h}^{-1}, \mathrm{Mg}^{2+}$ and $\mathrm{Na}^{+}-$exchangeable magnesium and sodium content in mmol(+) $\mathrm{kg}_{\text {of }}$ soil $^{-1}$.

Dehydrogenase activities determined using the DhA$\mathrm{Ca}(\mathrm{OH})_{2}$ procedure were correlated with factor 3 and not correlated with factor 1 and 2 at all (Fig. 1).

Dehydrogenase activities determined using the DhA$w b$ assay ranged from zero values in samples from the AE horizons of Albic and Gleyic Podzols, the Oh and Ah horizons of Endoeutric Cambisol without fertilization (C) and fertilized with serpentinite (S), and the Ofh horizons of unfertilized Albic Podzol (C) to $98.89 \mu \mathrm{mol} \mathrm{TPF} \mathrm{kg} \mathrm{of} \mathrm{soil}{ }^{-}$ ${ }^{1} \mathrm{~h}^{-1}$ in the sample from the Ofh horizons of Albic Podzol fertilized with dolomite (D) (Table 4). The lowest average activity of dehydrogenases was determined in the samples obtained from the AE horizons of Gleyic Podzols (0.01 $\mu$ mol TPF kg of soil ${ }^{-1} \mathrm{~h}^{-1}$ ), while the highest average values were determined in the samples from the Ofh horizons of Albic Podzol fertilized with dolomite $(84.10 \mu \mathrm{mol}$ TPF kg of soil ${ }^{-1} \mathrm{~h}^{-1}$, Table 4).

The results of the regression analysis show that the TPF values determined using the DhA-wb assay were significantly conditioned by the values of $\mathrm{pH}$ in $1 \mathrm{M} \mathrm{KCl}$, the sum of base cations (S), and the C:N ratio. These independent variables explain $c a .89 \%$ of the variance $\left(R_{a d j}^{2}=0.8866\right)$ of dehydrogenase activity of the examined soils determined using the 'DhA-wb' assay (Eq. (4)).

$$
\mathrm{DhA}-\mathrm{wb}=\mathrm{e}^{-26.203}(\mathrm{pH} \text { in } \mathrm{KCl})^{6.408}(\mathrm{~S})^{0.967}(\mathrm{C}: \mathrm{N})^{4.4358}
$$

where: DhA - wb - in $\mu$ mol TPF kg of dry soil ${ }^{-1} \mathrm{~h}^{-1}, \mathrm{e}-$ the base of the natural logarithm, $\mathrm{S}$ - the total of exchangeable base cations in mmol( $(+) \mathrm{kg}$ of soil ${ }^{-1}$ determined in $1 \mathrm{M}$ ammonium acetate solution, $\mathrm{C}: \mathrm{N}$ ratio - the ratio of the content of total C to total N.

Dehydrogenase activities determined using the DhAwb assay were strongly associated with factor 2 and 3, and very weakly correlated with factor 1 (Fig. 1).

Dehydrogenase activity values determined by the 'DhA-Th' method were lower from values obtained using the $\mathrm{DhA}-\mathrm{Ca}(\mathrm{OH})_{2}$ and $\mathrm{DhA}-\mathrm{CaCO}_{3}$ assays and a little lower from values obtained with the DhA-wb assay in soils with light acid or neutral reaction of soil. However, they were a little higher from values obtained with the use of the DhA-wb assay in soils with very acid soil reaction. The determined activities ranged from zero values (Calcaric Cambisol) to $64.57 \mu \mathrm{mol} \mathrm{kg}$ of soil ${ }^{-1} 1 \mathrm{~h}^{-1}$ (the sample from the Ofh Albic Podzol soil fertilized with dolomite). The lowest average values of DhA were noted in samples from the AE horizons of Albic Podzol as well as the $\mathrm{Oh}$ and Ah horizons of Endoeutric Cambisol fertilized with serpentinite (S) with the mean values amounting to 0.799 and $1.642 \mu \mathrm{mol} \mathrm{kg}$ of soil-1 $1 \mathrm{~h}^{-1}$, respectively. Higher average values were observed in samples from the Ah horizons of Calcaric Cambisol and the Ofh horizons of Albic Podzol fertilized with dolomite (D), with the mean values amounting to 6.270 and $46.143 \mu \mathrm{mol} \mathrm{kg}$ of soil ${ }^{-1} 1 \mathrm{~h}^{-1}$, respectively (Table 4).

On the basis of the regression analysis, it was found that the DhA-Th values were significantly conditioned by the sum of base cations ( $\mathrm{S}$ ), the value of the $\mathrm{C}: \mathrm{N}$ ratio, and the content of exchangeable sodium. The share of variance explained by the model describing the dehydrogenase activity of the examined soils determined with the 'DhA-Th' method as a function of $\mathrm{S}, \mathrm{C}: \mathrm{N}$ and $\mathrm{Na}^{+}$is approximately $69 \%\left(\mathrm{R}^{2}=0.6941\right.$, Eq. (5)):

$$
\text { DhA }-\mathrm{Th}=\mathrm{e}^{-13.7680}(\mathrm{~S})^{1.0327}(\mathrm{C}: \mathrm{N})^{3.0995}(\mathrm{Na}+)^{-1.0119}
$$

where: DhA-Th in $\mu$ mol TPF kg dry $\operatorname{soil}^{-1} \mathrm{~h}^{-1}, \mathrm{~S}-$ the sum of exchangeable base cations in mmol(+) kg of soil ${ }^{-1}$ determined in $1 \mathrm{M}$ ammonium acetate solution, $\mathrm{C}: \mathrm{N}$ ratio - 
the ratio of the content of total $\mathrm{C}$ to the content of total $\mathrm{N}$, $\mathrm{Na}^{+}-$the content of exchangeable sodium in mmol $(+) \mathrm{kg}$ of soil-1.

Dehydrogenase activity determined using the DhA-Th assay was related to both factor 2 and 3, but slightly less correlated with factor 1 (Fig. 1).

The TTC solution was added to the control soil samples (CSS) for determination of dehydrogenase activity with the $\mathrm{DhA}-\mathrm{Ca}(\mathrm{OH})_{2}$ and DhA-wb assays. Higher TPF concentrations were determined in CSS using the $\mathrm{DhA}-\mathrm{Ca}(\mathrm{OH})_{2}$ assay; they ranged from 0.001 (Endoeutric Cambisol, Ah, M) to $3.720 \mathrm{mg}$ TPF $\mathrm{ml}^{-1}$ (Gleyic Podzol, AE) with the mean concentration of $0.329 \mathrm{mg} \mathrm{TPF} \mathrm{ml}{ }^{-1}$ for all tested samples. Higher TPF concentrations were determined in strongly acidic sands (Albic and Gleyic Podzol), with the mean concentration of $1.3045 \mathrm{mg}$ TPF $\mathrm{ml}^{-1}$; lower concentrations were noted in the remaining samples with an average of $0.0422 \mathrm{mg} \mathrm{TPF} \mathrm{ml}^{-1}$. On the basis of the multiple regression analysis, it was found that the value of probable chemical reduction of TTC in the determination of DhA$\mathrm{Ca}(\mathrm{OH})_{2}$ depends mainly on the soil moisture content (Wh) and on the $\mathrm{C}: \mathrm{N}$ ratio, while the model of probable chemical reduction of TTC in the determination of the $\mathrm{DhA}-\mathrm{Ca}(\mathrm{OH})_{2}$ can be described by means of equation $6\left(R_{a d j}^{2}=0.6018\right)$ :

$$
\mathrm{TPF}_{\mathrm{DhA}-\mathrm{Ca}(\mathrm{OH})_{2}}=\mathrm{e}^{-9.70078}(\mathrm{C}: \mathrm{N})^{4.48791} \mathrm{Wh}^{-1.81381}
$$

where: $\mathrm{e}$ - base of natural logarithm, $\mathrm{C}: \mathrm{N}$ - the ratio of total $\mathrm{C}$ to total $\mathrm{N}, \mathrm{Wh}-$ moisture in weight $\%$.

When determining the DhA-wb in the control soil samples (CSS), lower TPF concentrations were detected ranging from 0.007 to $0.137 \mathrm{mg} \mathrm{TPF} \mathrm{ml}^{-1}$ (Albic Podzol AE and Ofh without fertilization, respectively). Lower TPF concentrations were found in sand CSS, with an average of $0.0211 \mathrm{mg} \mathrm{TPF} \mathrm{ml}{ }^{-1}$ while higher ones were found in CSS of strongly acidic organic soil samples (samples from the Ofh horizon), with an average of $0.0813 \mathrm{mg} \mathrm{TPF} \mathrm{ml} \mathrm{m}^{-1}$.

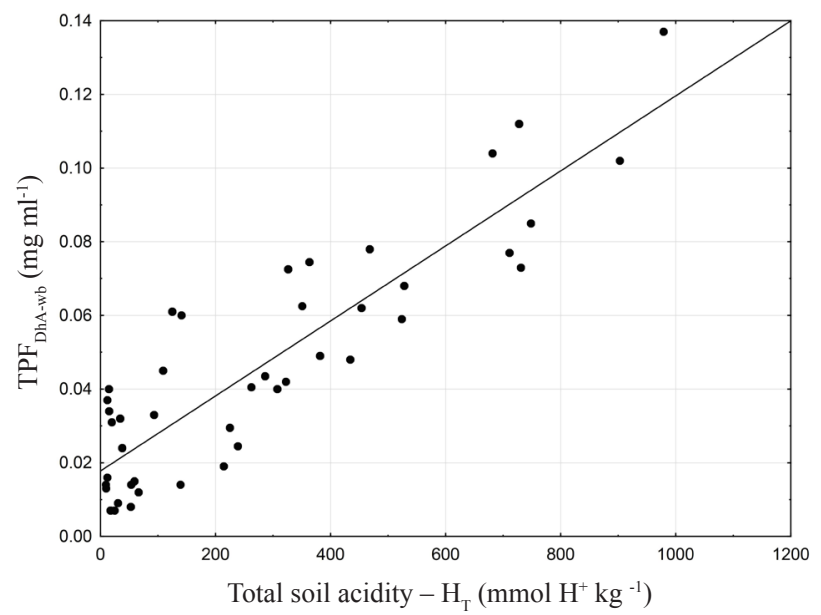

Fig. 2. Relationship between reduction of TTC in control soil samples $\left(\mathrm{mg} \mathrm{TPF} \mathrm{ml}^{-1}\right)$ and total soil acidity $\left(\mathrm{mmol}(+) \mathrm{kg}\right.$ of soil $\left.{ }^{-1}\right)$ in analyzed soil samples by the DhA-wb procedure.
A linear relationship was found between the values of the determined concentrations of TPF in CSS when determining the DhA-wb and the values of total acidity (Fig. 2). On the basis of the multivariate regression analysis, it was found that over $78 \%\left(R_{a d j}^{2}=0.7844\right)$ of the probable chemical reduction of TTC when determining the DhA-wb is explained by means of a simple linear regression model where the total acidity is the independent variable (Eq. (7), Fig. 2).

$$
\mathrm{TPF}_{\text {DhA-wb }}=0.017781+0.000102 \mathrm{H}_{\mathrm{T}}
$$

where: $\mathrm{TPF}_{\mathrm{DhA}-\mathrm{wb}}$ concentration of TPF determined by the DhA-wb assay in $\mathrm{mg} \mathrm{ml}^{-1}$ of the extract, $\left(\mathrm{H}_{\mathrm{T}}\right)$ - total soil acidity in $\mathrm{mmol}(+) \mathrm{kg}$ of soil $^{-1}$.

\section{DISCUSSION}

Dehydrogenase is considered an indicator of overall microbial activity because it occurs intracellularly in all living microbial cells. The use of dehydrogenase activity as an index of overall microbial activity has been suggested by many authors (Alef and Nannipieri, 1995 Casida et al., 1964; Lenhard, 1956; Nannipieri et al., 1990). It can be assumed that the quality of the soil corresponds to the soil microbial activity. Therefore, one can expect a relationship between the activity of dehydrogenases and the physicochemical properties of soils, which determine their quality, such as $\mathrm{pH}$, sorption capacity, degree of base saturation, etc. In the present study, the TPF values determined using the DhA-wb assay were significantly positively correlated with properties such as: $\mathrm{pH}$ in $\mathrm{H}_{2} \mathrm{O}$ and $1 \mathrm{M} \mathrm{KCl}$, the sum of base cations, the degree of base saturation, the content of exchangeable $\mathrm{Ca}$ and $\mathrm{Mg}$ forms, and significantly correlated with cation sorption capacity $(\mathrm{T})$. Contrary to the expectations, dehydrogenase activity values indicated by means of the DhA-Ca(OH) ${ }_{2}$ and DhA-Th assays were not correlated with each other. Dehydrogenase activity values determined using the $\mathrm{DhA}-\mathrm{CaCO}_{3}$ procedure were correlated to a slightly lesser extent with the $\mathrm{pH}$ values of the samples. Among all the samples analysed with the multiple regression analysis, a significant effect of $\mathrm{pH}$ in the solution of $1 \mathrm{M} \mathrm{KCl}$ was demonstrated on the values of dehydrogenase activity identified solely with the DhA-wb assay. Similar results were obtained in Mediterranean forest soils in which the use of the multivariate regression analysis demonstrated the $\mathrm{pH}$ as the best indicator (predictor) of dehydrogenase activity (Quilchano and Marañón, 2002). On the basis of the relationships identified in this study between the determined DhA values with the $\mathrm{pH}$ values of the examined soil samples, it may be assumed that the property which determines the level of dehydrogenase activity most efficiently is the $\mathrm{pH}$ of the examined soils. The most surprising, unexpected results in the experiments were the highest values of dehydrogenase activity obtained using the $\mathrm{DhA}-\mathrm{Ca}(\mathrm{OH})_{2}$ method in the samples from the AE horizons of podzol sandy soils, strongly acidic, with low sorption 
capacity (samples 1-10), while the values of dehydrogenase activity determined by the other procedures in these samples were the lowest (Table 4). When determining dehydrogenase activity using this assay (Januszek et al., 2007), the highest content of TPF was recorded in highly acidic sandy soil and a lower content in less acidic samples of silty and clayey soil. The $\mathrm{pH}$ measurements of the suspensions used for determination of the activity of dehydrogenases show that the soil suspensions prepared with $\mathrm{Ca}(\mathrm{OH})_{2}$ had a higher $\mathrm{pH}$, closer to the optimum $\mathrm{pH}$ values for activity of dehydrogenases, than the suspensions containing $\mathrm{CaCO}_{3}$ (Januszek et al., 2007). 72 to $100 \%$ of bacterial colonies and actinomycetes and only $5 \%$ of fungal colonies in different Indian soils were capable of using TTC as an electron acceptor (Praveen-Kumar and Tarafdar, 2003). In light of the study results, the low dehydrogenase activity determined by the DhA-wb assay in the examined strongly acidic soils seems to be justified in view of the likely dominance of fungi in these soils, which has been confirmed by the results of studies on the relationship of fungi to bacteria in strongly acidified soils (Rous et al., 2010).

The neutral or slightly alkaline $\mathrm{pH}$ of the sandy soil samples probably created conditions favourable for the growth of microorganisms in 24 hours of incubation, which may explain the high values of dehydrogenase activity determined using the $\mathrm{DhA}-\mathrm{Ca}(\mathrm{OH})_{2}$ assay. An additional cause of the high values of dehydrogenase activity in the samples of the AE levels of podzol soil determined using DhA-Ca $(\mathrm{OH})_{2}$ could be the presence of large quantities of calcium cations, derived from dissociation of $\mathrm{Ca}(\mathrm{OH})_{2}$ as an activator of dehydrogenases, as demonstrated by Karr and Emerich (2000) using the example of the NADP ${ }^{+}$dependent isocitrate dehydrogenase from Bradyrhizobium japonicum.

Dehydrogenase activity results obtained using the $\mathrm{DhA}-\mathrm{Ca}(\mathrm{OH})_{2}$ procedure allow a conclusion that this method is not suitable to assess the activity of dehydrogenases in acid soils with low sorption capacity, ie the sandy soils analysed in this case (samples Nos 1-10). This procedure can be useful for highly buffered soils and for a shortened time of incubation with TTC, which prevents microbial growth and guarantees $\mathrm{pH}$ closer to the optimal value for dehydrogenases; it only allows determination of the DhA of microorganisms that are active and able to reduce TTC in a given soil.

The low concentrations of TPF determined with the DhA-wb and DhA-Th assays in the sandy samples may also result from the use of too low a temperature, not optimal for the activity of dehydrogenases, as well as from the non-optimal TTC concentration. The results of research by Ghaly and Mahmoud (2007) showed that the optimal conditions for determination of dehydrogenase activity of Aspergillus niger active cells were the incubation temperature of $55^{\circ} \mathrm{C}$ and $\mathrm{pH} 9$, and TTC concentration varied depending on the age of the colony of Aspergillus niger. Friedel et al. (1994) suggest that the optimum concentrations of TTC should be determined individually for each soil.

The addition of TTC or INT to sterilized control samples allows detection of formazan from chemical (abiotic) reduction, which is not caused by soil microorganisms but by organic and mineral substances present in soil. This eliminates the errors to which the tested methods are subject (Shaw and Burns, 2006; Stępniewska, 1987). The higher concentrations of formazan recorded in the autoclaved rather than in the non-autoclaved samples in the case of the DhA-wb assay may result from changes in both organic and mineral substances during the autoclaving of soil samples. Changes in physical and chemical properties of soils under different methods of sterilization are reported by Berns et al. (2008). As a result of soil autoclaving, the authors noted substantial changes in the particle size, leading to an increase in their outer surface, a drastic increase in soluble, non-purgeable organic carbon, and a decrease in $\mathrm{pH}$ due to the release of organic acids from soil organic matter. Released into the solution, soluble organic compounds of carbon may be electron donors, thus contributing to the reduction of TTC. A higher chemical reduction of TTC in the autoclaved samples of soils with low microbial activity prevents determination of TPF reduced biochemically and, hence, low levels of dehydrogenase activity. Thus, dehydrogenase activity was not determined using the DhA-wb assay in many sandy, highly acidic soil samples. Berns et al. (2008) conclude that there is a need for other forms of sterilization of control samples than autoclaving; the authors state that less intense changes in the physical and chemical properties of soil samples follow from sterilization by gamma radiation. Research carried out by Stępniewska (1987) shows that adding toluene to soil control samples does not solve the problem because the addition of toluene caused an increase in TTC chemical reduction. The higher values of TPF determined using the $\mathrm{DhA}-\mathrm{Ca}(\mathrm{OH})_{2}$ assay may result from more effective reduction of TTC at higher $\mathrm{pH}$ values, particularly in soils with low sorption capacity (Gleyic and Albic Podzol). The $\mathrm{pH}$ values were higher in the sandy soil and lower in soil samples which were more buffered after adding the same amount of $\mathrm{Ca}(\mathrm{OH})_{2}$ (Januszek et al., 2007).

In light of the results obtained, the statement by Beyer et al. (1993) that 'without simultaneous studies of other microbiological parameters (such as microbial biomass, ATP level, enzyme activity), measurement of dehydrogenase activity creates confusion and may inhibit important ecological comparisons of soils' is particularly true in the case of poor forest soils, strongly acidified with domination of fungi. In this type of soils, there are in fact the biggest differences in dehydrogenase activity resulting from the assay used. 
Microbial activity plays an important role in regulating soil quality. The microbiological processes taking place in soil are at the centre of many ecological functions (Nannipieri et al., 1990). Therefore, development of a universal method that will make it possible to identify clearly DhA activity in forest soils is a very important task in the field of soil science.

\section{CONCLUSIONS}

1. Values of dehydrogenase activity of forest soils depend on the assay used. Among the methods used for determination of dehydrogenase activity in the examined soil samples, the assay that best reflects the characteristics of the analysed soils appears to be the modified procedure by Casida et al. without the addition of buffer or $\mathrm{pH}$ adjusting salt. The DhA-wb values obtained with this method are correlated strongly with the properties governing soil quality, such as $\mathrm{pH}$, degree of base saturation $(\mathrm{V} \%)$, the sum of base cations (S), the value of the $\mathrm{C}: \mathrm{N}$ ratio, and the concentration of the exchangeable form of $\mathrm{Ca}^{2+}$ and $\mathrm{Mg}^{2+}$.

2. The modified assay by Casida et al. with the addition of $\mathrm{Ca}(\mathrm{OH})_{2}$ instead of $\mathrm{CaCO}_{3}$ for determination of $\mathrm{DhA}$ distorts the image of microbiological activity in soils with low sorption capacity, probably due to the more optimal $\mathrm{pH}$ for microbial growth during the $24 \mathrm{~h}$ incubation. However, this method may be useful for evaluation of the activity of dehydrogenases in strongly buffered soils, when using a short incubation time.

3. Determination of dehydrogenase activity requires assessment of the degree of chemical reduction of TTC in analysed samples. In the autoclaved control samples with strongly acidic and acidic reaction, TPF had higher concentrations than in the measurement samples, indicating chemical rather than biochemical reduction of TTC. Therefore, it is necessary to use other methods of soil sterilization than autoclaving, a process that results in significant changes in soil properties. Due to the possibility of chemical reduction of TTC, it is more secure to compare the activity of dehydrogenases in soils with similar physicochemical properties.

4. Among the studied physicochemical and chemical properties of the soil, the soil reaction affects soil dehydrogenase activity most efficiently. The highest activity regardless of the assays used (except DhA-Ca(OH) ${ }_{2}$ ) was recorded in the soils with the neutral or weakly acidic reaction.

5. The autoclaved strongly acidic samples of control soils showed high concentrations of TPF probably due to chemical reduction of TTC, which was proportional to the total acidity of soil. There is, therefore, a need for sterilization other than autoclaving, ie a process that results in significant changes in soil properties, thus helping to increase the chemical reduction of TTC.
6. Assessment of microbial activity based on the determination of DhA by sofar recommended methods using TTC in strongly acidic forest soils, which are dominated by fungi, seems to be controversial in the light of the present research findings as well as the results obtained by Praveen-Kumar and Tarafdar (2003).

\section{REFERENCES}

Alef K. and Nannipieri P., 1995. Enzyme activities. In: Methods in applied, Soil Microbiology and Biochemistry (Eds K. Alef, P. Nannipieri). Academic Press, London-New YorkSan Francisco.

Benefield C.B., Howard P.J.A., and Howard D., 1977. The estimation of dehydrogenase activity, Soil Biol. Biochem., 9, 67-70.

Berns A.E., Phlilipp H., Narres H.D., Burauel P., Vereecken P., and Tappe W., 2008. Effect of gamma-sterilization and autoclaving on soil organic matter structure as studied by solid state NMR, UV and fluorescence sopectroscopy. Eur. J. Soil Sci., 59, 540-550.

Beyer L., Wachendorf C., Elsne D.C., and Knabe R., 1993. Suitability of dehydrogenase activity assay as an index of soil bilogical activity, Biol. Fertil. Soil, 16, 52-56.

Brookes P.C., 1995. The use of microbial parameters in monitoring soil pollution by heavy metals. Biol. Fertil. Soil, 19, 269-275.

Brzezińska M., Stępniewska Z., and Stępniewski W., 2001. Dehydrogenase and Catalase Activity of Soil Irigated with Municipal Wastewater, Polish J. Environ. Studies, 10, 307-311.

Camiña F., Trasar-Cepeda C., Gil-Sotres F., and Leirós C., 1998. Measurement of dehydrogenase activity in acid soils rich in organic matter. Soil Biol. Biochem., 30, 1005-1011.

Casida L.E., Klein D.A., and Santoro T., 1964. Soil dehydrogenase activity. Soil Sci., 98, 371-376.

Chodak M., Pietrzykowski M., and Niklińska M., 2009. Development of microbial properties in a chronosequence of sandy mine soils. Applied Soil Ecol., 41, 259-268.

Friedel J., Mölter K., and Fisher W., 1994. Comparison and improvement of methods for determining soil dehydrogenase activity by using triphenylotetrazolium chloride and iodonitrotetrazolium chloride. Biol. Fertil. Soil, 18, 291-296.

Gajda A.M., Przewłoka B., and Gawryjołek K., 2013. Changes in soil quality associated with tillage system applied. Int. Agrophysics, 27, 133-141.

Ghaly A.E. and Mahmoud N.S., 2007. Effect of tetrazolium chloride concentration, $\mathrm{O}_{2}$, and cell age on dehydrogenase activity of Aspergillus niger. Appl. Biochem. Biotechnol., 136, 207-222.

Gong P., 1997. Dehydrogenase activity in soil: a comparison between the TTC and INT assay under their optimum conditions, Soil Biol. Biochem., 29, 211-214.

Januszek K., Błońska E., and Stanik P., 2007. Comments concerning determination of dehydrogenase activity in soil by the TTC-Formazan test (in Polish). Acta Agrophysica, 9(3), 635-644.

Karr D.B. and Emerich D.W., 2000. Bradyrhizobium japonicum Isocitrate Dehydrogenase exibit calcium-dependent hysteresis. Arch. Biochem. Biophysics, 376(1), 101-108. 
Klose S., Acosta-Martínez V., and Ajwa H.A., 2006. Microbial community composition and enzyme activities in a sandy loam soil after fumigation with metyl bromide or alternative biocides. Soil Biol. Biochem., 38, 1243-1254.

Lenhard V.G., 1956. Die Dehydrogenaseaktiwität des Bodens als Mass für die Microorganismentätigkeit im Boden. Z Pflanzenernähr Bodenkd., 73, 1-11.

Lityński T., Jurkowska H., and Gorlach E., 1976. ChemicalAgricultural Analysis (in Polish). PWN, Warsaw, Poland.

Malkomes H.P., 1991. Vergleich der TTC- und INT-reduction zum nachweis von pflanzenschutzmittelwirkungen auf die dehydrogenaseaktivität im boden. Nachrichtenbl. Dtsch. Pflanzenschutzd, 43, 52-57.

Nannipieri P., Grego S., and Cecanti B., 1990. Ecological significance of the biological activity in soil. In: Soil Biochem. (Eds J.M. Bollag, B. Stotzky). Dekker, New York, USA.

Paradelo R. and Barral M.T., 2009. Effect of moisture and disaggregation on the microbial activity of soil, Soil Till. Res., 104(2), 317-319.

Praveen-KumarB.andTarafdarJ.C.,2003.2,3,5-Triphenyltetrazolium chloride (TTC) as an electron acceptor of culturable soil bacteria, fungi and actinomycetes. Biol. Fertil. Soil, 38, 186-189.

Quilchano C. and Marañón T., 2002. Dehydrogenase activity in Mediterranean forest soils. Biol. Fertil. Soil, 35, 102-107.

Ross D.J., 1971. Some factors influencing the estimation of dehydrogenase activities of some soils under pasture. Soil Biol. Biochem., 3, 97-110.

Rossel D. and Tarradellas J., 1991. Dehydrogenase activity of soil micloflora: significance in ecotoxicological tests. Environ. Toxicol Water Qual., 6, 17-33.

Rous J., Brookes P.C., and Bååth E., 2010. Investigating the mechanisms for the opposing $\mathrm{pH}$ relationships of fungal and bacterial growth in soil. Soil Biol. Biochem., 42, 926-934.
Shaw L.J. and Burns R.G., 2006. Enzyme Activity Profiles and Soil Quality. In: Microbiological Methods for Assessing Soil Quality (Eds J. Bloem, D.W. Hopkins, A. Benedetti). CABI Publishing, London, UK.

Skawryło-Bednarz B. and Krzepilko A., 2009. Effect of different fertilization on enzyme activity in rhizosphere and nonrhizosphere of amaranth. Int. Agrophys., 23, 409-412.

StatSoft Inc., 2011. STATISTICA Version 10, Computer software.

Stevenson I.L., 1959. Dehydrogenase activity in soils. Can. J. Microbiol., 5, 97-110.

Stępniewska Z., 1987. $\mathrm{Fe}^{2+}$ interference in determination of dehydrogenase activity of soils. Polish J. Soil Sci. Soil Chem., 21(1), 25-31.

Trasar-Cepeda C., Leiros M.C., Seoane S., and Gil-Sotres F., 2000. Limitations of soil enzymes as indicators of soil pollution. Soil Biol. Biochem., 32, 1867-1875.

Trevors J.T., 1984. Effect of substrate concentration, inorganic nitrogen, $\mathrm{O}_{2}$ concentration, temperature and $\mathrm{pH}$ on dehydrogenase activity in soil. Plant Soil, 77, 285-293.

Von Mersi W. and Schinner F., 1991. An improved and accurate method for determining the dehydrogenase activity of soils with iodonitrotetrazolium chloride. Biol. Fertil. Soils, 11, 216-220.

Włodarczyk T. Stępniewski W., and Brzezińska M., 2002. Dehydrogenase activity, redox potential, and emissions of carbon dioxide and nitrous oxide from Cambisols under flooding condition. Biol. Fertil. Soils, 36, 200-2006.

Wolińska A., 2010. Dehydrogenase activity of soil microorganisms and oxygen availability during reoxidation process of selected mineral soils from Poland (in Polish). Acta Agrophysica Monographiae, 3, 1-88.

WRB, 2006. World reference base for soil resources. A framework for international classification, correlation and communication. World Soil Resources Reports 103. FAO UN, Rome. 